\title{
Euphemism in Biblical Hebrew and the euphemistic 'bless' in the Septuagint of Job
}

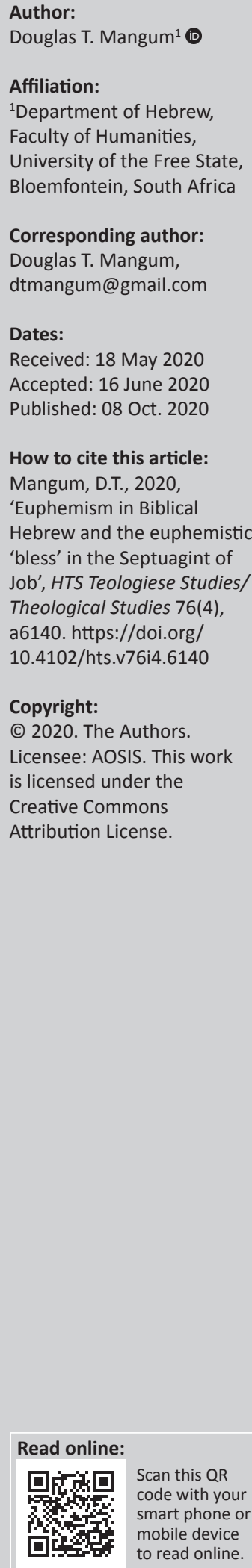

The Septuagint (LXX) generally approached the antiphrastic, euphemistic use of ברך [bless]

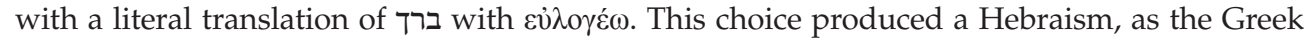
verb is not generally used antiphrastically. The translators may have expected the Greek audience to track with the figurative usage. Job contains four of the six uses of this euphemism,

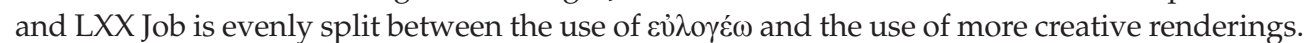
These creative renderings in Job 1:5 and 2:9 reflect the exegesis of the translator.

Contribution: The contribution of this research article is its focus on the phenomenon of euphemism in Biblical Hebrew and the implications of non-literal renderings in the Septuagint for a theologically-significant Hebrew euphemism. The article fits within the scope of the journal as a contribution to this special collection on the Septuagint.

Keywords: Biblical Hebrew; Septuagint; Euphemisms; Tiqqunê soferim; Book of Job; Hebrew Bible; Translation technique; Translation studies.

\section{Introduction}

This study focuses on euphemism in the Bible, specifically the euphemistic use of בbless] in Biblical Hebrew (BH) and its rendering in the Septuagint (LXX). Four of the six places in the Hebrew Bible where 'bless' is used with the sense of 'curse' are found in the prologue to the Book of Job $(1: 5,11 ; 2: 5,9)$; therefore, the interpretation of this word in Job is a central concern of the study. One reason for this study is that many exegetical works on Job give only passing attention to the fact that the word ברך is being used in a sense opposite to its denotative meaning. They generally offer little beyond noting the word as a euphemism (e.g. Habel 1985:88; Pope 1973:8). This study fills the gap by articulating how the phenomenon of euphemism functions with relation to sacred speech and how euphemism factors in communication, including translation. Furthermore, the LXX of Job is often characterised as relatively free of Hebraisms and reflecting Greek of a 'good literary quality' (Cox 2007:667). The renderings of the euphemistic ברד in LXX Job reflect both the use of Hebraism and the use of good idiomatic Greek. One aim of this study is to identify the exegetical strategies of the LXX translator for Job 1:5, 1:11, 2:5 and 2:9. The objective is to illustrate the ways in which the LXX translator interpreted the biblical text.

This article is organised as follows. The next section explains the theoretical and methodological background of the study in Translation Studies and sociolinguistics. This is followed by a survey of the phenomena of euphemism and dysphemism in $\mathrm{BH}$ and a discussion of the scribal emendations (tiqqunê soferim) so often cited as evidence of the Hebrew scribes' caution surrounding references to God. Then, the focus turns to the specific phenomenon of the euphemistic use of ברך and its rendering in LXX Job.

\section{Theoretical and methodological basis}

The theoretical and methodological basis of this study is found in Translation Studies and sociolinguistics. Translation Studies informs my general approach to analyse the ancient versions by providing a conceptual framework for describing the strategies employed by translators (Baker 2011; Toury 2012; for more on methodology, see Mangum 2017:78-142). The study of linguistic taboos and the use of euphemism and dysphemism is part of sociolinguistics and pragmatics (Allan \& Burridge 1991, 2006).

Euphemisms are especially common across languages for the same types of taboo topics, regardless of language or culture (see Mangum 2017:125-130). Taboos are social norms that place constraints on behaviour, often with reference to religion or morality. For example, taboos may be associated with a Note: Special Collection entitled Septuagint SA, sub-edited by Johann Cook (SUN). 
sacred space, such as the restrictions in biblical law over who was permitted to enter the tabernacle (Nm 1:51;18:22). Linguistic taboos relate to words or phrases that should be avoided in polite discourse because of their association with taboo topics like the sacred, death, disease, sexuality or body parts and bodily processes associated with excretion or sexuality.

Euphemism is characterised by avoidance language. The choice of a particular word or expression is influenced by a concern for avoiding potentially offensive phrasing, shielding the audience from the full negative impact that another word or expression would have. Dysphemism is characterised by offensive language. The choice of a particular word or expression is motivated by a deliberate desire to offend or insult. Allan and Burridge (1991) define dysphemism as:

$[A] n$ expression with connotations that are offensive either about the denotatum or to the audience, or both, and it is substituted for a neutral or euphemistic expression for just that reason. (p. 26)

Although euphemism and dysphemism are used for opposite purposes, they reflect two sides of the same phenomenon - the choice to conform to social norms or to deliberately violate those norms. This phenomenon can be defined with reference to 'concerns about face' and 'face effects' (Allan \& Burridge 1991:4, 7) - that is, the choice is motivated by a desire either to save face (for any of the participants) or to cause shame and offense (lose face).

Many figures of speech can be categorised as euphemisms because they function as substitutes for taboo words and phrases. (Although the term 'taboo' has connotations of inviolability, the degree of social censure inspired by an infelicitous statement varies greatly according to culture and language. Violation of certain linguistic taboos had severe consequences in Israelite society [see Lv 24:10-16].) Dysphemisms function as intentionally insulting substitutes for polite or neutral words and phrases. Euphemism is used to avoid social censure and disapproval. Dysphemism is used to assert social status or manoeuvre for status by downgrading or diminishing the status of another. In general, euphemisms conceal socially sensitive situations to save face, whilst dysphemisms deliberately denigrate and disparage an opponent. These figures of speech are heavily dependent on the social and cultural context of their use because they are meant to say more than the meanings of the words denote. Euphemism makes use of a language's resources for producing figurative expressions; therefore, many types of euphemisms are simply applications of general strategies for producing figures of speech like metaphors, metonymy, wordplay or hyperbole. Application in a relevant context is what makes an expression a euphemism. The study of this linguistic phenomenon makes use of semantics, pragmatics, communication theory and sociolinguistics. The pragmatic purpose of a figurative expression is what defines it as a euphemism or dysphemism.

\section{Euphemism and dysphemism in the Hebrew Bible}

Biblical Hebrew has its fair share of euphemisms and dysphemisms, although both are not always recognised as such. Despite the ubiquity of euphemism and dysphemism in language usage, both spoken and written, few sustained treatments of the euphemisms and dysphemisms used in $\mathrm{BH}$ have been conducted. Schorch (2000) is the only booklength study to my knowledge. Other discussions of $\mathrm{BH}$ euphemisms are found in dictionary or encyclopaedia articles, such as Opelt (1966), Pope (1992), Paul (2007), Noegel (2013) and Warren-Rothlin (2013).

Biblical Hebrew euphemisms tend to cluster around the common list of taboo topics mentioned above. 'Euphemism' is a pragmatic category that depends on the language user's definition of the situation and their construal of an expression as designed to conceal a taboo subject. Linguistic taboos change over time in most cultures; therefore, it is reasonable to assume that the writers, scribes and translators of the Hebrew Bible may have had varying degrees of tolerance for openly discussing certain subjects, because the transmission of the text by all estimations happened over centuries. Later scribes and translators may have been confronted with texts that used euphemism where a taboo no longer existed or openly discussed subjects that were now considered taboo.

Next, I briefly survey the topics of euphemism and dysphemism in $\mathrm{BH}$ before moving into the main discussion of the euphemistic use of ברך [bless] in BH and its rendering in the LXX. The category of dysphemism is introduced because a use of קלל [curse] with reference to God in the biblical text could be construed as a dysphemism, a violation of linguistic taboos over offending the divine.

\section{Euphemisms in Biblical Hebrew}

Euphemisms in $\mathrm{BH}$ range from conventional substitutions that have become commonplace (like the avoidance of ידע specific verbs for sexual activity by substituting verbs like or שכב) to creative wordplays that let a suggestive double entendre stand (like much of the imagery of Song of Songs; compare the use of ג [garden] in Song of Songs 4; see Paul 2005:271-284). Unfortunately, as is the case with much figurative language, these euphemisms generally get lost in translation; therefore, readers of the Hebrew Bible in any translation - ancient or modern - may pass over euphemistic statements, unaware of the writer's probable (or at least possible) meaning.

Language users tend to produce euphemisms following the same basic strategies, regardless of language or culture. The primary strategy is substitution, that is, replacing a taboo word or expression with a more acceptable word or expression. Substitutions are often metonymies: a related word within the same conceptual domain is substituted for a word the speaker or writer wishes to avoid (see Chau 2014). All euphemisms are technically substitutions of some sort, but languages also use borrowing, semantic remodelling, metaphor, wordplay, circumlocution and generalisation to produce euphemisms (Allan \& Burridge 1991:14-20).

Biblical Hebrew euphemisms tend to be classifiable as substitution by metaphor (e.g. ר. [ [pit], for the underworld; 
Is 38:18), metonymy (e.g. שֶׁם [name], for God's name; Lev 24:11), antiphrasis (e.g. בית הַחָפְּשִשית [house of freedom], for a place of confinement and isolation; $2 \mathrm{Ki} \mathrm{15:5)} \mathrm{and}$ periphrasis or circumlocution (e.g. the Cushite's lengthy

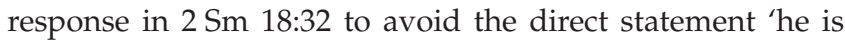
dead'; on strategies used for euphemisms in $\mathrm{BH}$, see Schorch 2000:235-251). Zevit (2011:396) states, 'Israelite authors preferred euphemisms and circumlocutions most of which are transparent'. Of course, circumlocution is itself a type of euphemism. I believe he overstates the transparency of the euphemisms in $\mathrm{BH}$ for readers less familiar with biblical idiom.

Other common $\mathrm{BH}$ euphemisms include expressions to

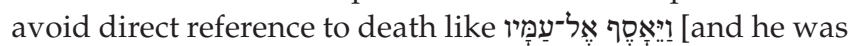
gathered to his people] (Gn 25:8) or sexual intercourse like לִגְלוֹת עֶרונה [to uncover nakedness] (Lv 18:6-18). Everyday

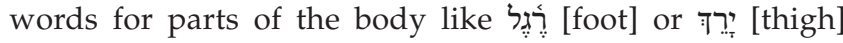
may also denote the private parts of the body (i.e. genitalia; see Gn 24:2, Dt 28:57 and Is 7:20; for additional examples, see Noegel 2013:869-880).

\section{Dysphemism in Biblical Hebrew}

The category of dysphemism in $\mathrm{BH}$ is largely evident in the disparaging labels used to refer to deities other than YHWH, the idols representing those deities or the practices associated with their worship. For example, the Hebrew word תוֹעָבָה, commonly translated as 'abomination', is used to label a variety of detestable religious practices (Lv 18:2630; Dt 7:25-26; 12:31; 1 Ki 14:24). Likewise, the term [detested thing] (also spelt שִקקוּץ) was used synonymously with תisth for idolatrous practices. The dysphemistic use of نשקִץץ is especially clear in 2 Kings 23:

The king defiled the high places ... that Solomon king of Israel built

for Ashtoreth the abomination (שיקקָ) of the Sidonians and

for Chemosh the abomination (שִקיָ) of Moab and

for Molech the abomination (תוֹעָבה) of the Ammonites. (v. 13; author's translation)

Instead of objectively reporting that Ashtoreth, Chemosh and Molech were the 'gods' of the nearby nations, the writer labels them abominations. With Ashtoreth and Molech, the very names of the deities appear to be dysphemistic, with Ashtoreth a corruption of Astarte and Molech possibly a corruption of Milcom (with Molech, the derivation of his name and his association with Milcom are more uncertain [Heider 1999:581-582; Puech 1999:575-576]). The common explanation for these corruptions is that the vowels of the word בּُשֶת [shame] were applied to vocalise the word in a derogatory way much like names with a בּَِ [lord] theophoric element were remodelled with בּ̇שֶת, such as with the use of Ishbosheth for Eshbaal in 2 Samuel (compare 1 Chr 8:33 and 2 Sm 2:8; see Pope 1992:725). This use of בּ̇שֶת was also dysphemistic and motivated by polemics against worship of the Canaanite deity Baal (Tov 2012:247-248). Because this latter change is found primarily in proper names, the translation of the name in the versions does not generally provide any indication of whether the translator understood its dysphemistic meaning (e.g. LXX at 2 Sm 2:8 just transliterates with $\mathrm{I} \varepsilon \beta 0 \sigma \theta \varepsilon)$.

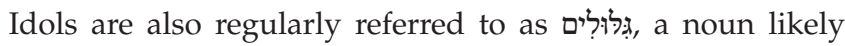
derived from the root גלל [roll] and related to nouns meaning 'dung'. The use of גוּלוּלוּלים in BH is always dysphemistic, and the word seems certainly to have been coined by vocalising

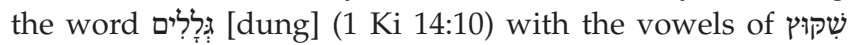
[detested thing]. These dysphemisms tend to be translated straightforwardly in the ancient versions, either with neutral terms simply meaning 'idols' or with terms from the same semantic domain of abhorrence.

\section{Euphemism and the tiqqunê soferim}

With euphemistic expressions in the Hebrew Bible, it is difficult to determine at what point in the textual transmission the substitution was made. The textual traditions known as the tiqqunê soferim [corrections of the scribes] attribute changes to the text of scripture to later scribes who were uncomfortable with anthropomorphic, blasphemous or indelicate expressions used in relation to YHWH (see Ginsburg 1897:347-363). Several midrashic texts include these lists in their comments to Exodus 15:7 (e.g. Mekhilta of Rabbi Ishmael, Yalkut Shimeoni and Midrash Tanhuma; see Tov 2012:59-61). These lists vary in providing anywhere from 7 to 17 cases of 'corrections'. The scribal changes typically reflect minor orthographic alterations designed to make the text say something other than what it originally said, regardless of whether the correction makes sense. Many of the examples consist of a simple change of suffix (Ginsburg 1897:352-362). This type of alteration is not a euphemism per se, but it was motivated by the same sort of taboos that lead language users to develop euphemisms. Specifically, these scribal corrections were motivated by fear and reverence for the sacred; the scribes were uncomfortable with transmitting a text that spoke directly in a derogatory fashion about God, even if the text itself was condemning such behaviour. These corrections are relevant to determine whether the antiphrastic use of ברך was part of the earliest text of Job or introduced later.

Tov (2012:60) is not convinced that these necessarily reflect 'real corrections' made by the scribes themselves as they copied the consonantal text because of the minimal nature of the alterations. The scribes copying the Hebrew consonantal text could have made even more significant changes if the content of the text troubled them. Because that did not happen, it is more likely the 'corrections of the scribes' reflect much later exegetical interference at a time when the skeletal structure of the consonantal text was fixed to the point that more involved rewritings of the content were impossible.

The tiqqune soferim open up the possibility that some of the euphemistic phrasing in the Hebrew text is the product of a later redactor, not the biblical writer. This possibility is 
ברד relevant for euphemistic substitutions like the use of [bless] for קלל [curse] in passages like 1 Kings 21 and Job 1-2. Although it might be assumed that later scribes made this change (along with the other 'corrections of the scribes'), it seems more likely that the biblical writers originally wrote the antiphrastic euphemism. Tov (2012:61) observes that it is surprising that the scribes did not intervene more significantly in their so-called corrections; his observation is relevant here because if the euphemistic substitution of ברך was a scribal alteration, it could reflect such a more intensive textual alteration. The minimal nature of the changes in the lists of tiqqunê soferim suggests that the antiphrastic substitutions either date to an earlier period of scribal activity or they are the phrasings of the biblical writers. The implication is that the euphemistic substitutions found in the Hebrew Bible should be considered part of the source text the translators of the LXX worked from unless there is compelling textual evidence to reconsider whether the version reflects a different Vorlage. Taboos against offending the sacred are strong enough that more significant adaptation of the source text by the translator might even be expected, especially in a more literary translation such as that of LXX Job.

\section{ברך The Biblical Hebrew euphemism and the Septuagint}

Many examples of euphemism in $\mathrm{BH}$ can be found that revolve around the meaning of a single word. The euphemistic use of a single word is difficult to analyse in the LXX because of the tendency towards a direct translation without regard for the underlying semantics of the usage. That is, the LXX often offers an imitative, word-for-word translation.

As discussed above, the primary concern with the 'corrections of the scribes' related to avoiding language that was irreverent or blasphemous. Allan and Burridge (1991:37) explain that 'taboos on the names of gods seek to avoid metaphysical malevolence by counteracting possible blasphemies (even, perhaps, profanities) that arouse their terrible wrath'. Biblical euphemisms related to speaking against God should probably be understood against this anthropological background as a fear-based taboo, meaning that the euphemism originated from fear that actually speaking badly about a god would draw the god's wrath on oneself. The power of such a taboo changes over time; therefore, whilst the Hebrew scribes may have altered the text to avoid irreverent references to God, later translators may have not felt as strongly against transmitting a text that stated directly that someone cursed God (e.g. Cox [1990:124] reports that the Greek translator referred to as 'ho Hebraios' rendered ברך with $\beta \lambda \alpha \sigma \varphi \eta \mu \varepsilon \dot{\varepsilon} \omega$ [blaspheme] at Job 2:5).

In the Hebrew Bible, the most well-known example of euphemistic avoidance of blasphemy is the use of ברך [bless] with the meaning of 'curse' (apparently as a substitution for קלל [curse]). This euphemistic substitution occurs six times (cf. Table 1) but in only two different literary contexts (1 Ki 21:10, 13 [LXX 3 Kingdoms 20:10, 13]; Job 1:5, 11; 2:5, 9).
TABLE 1: The rendering of the Biblical Hebrew antiphrastic use of ברך in the Septuagint.

\begin{tabular}{|c|c|c|}
\hline Verse & MT & LXX \\
\hline \multirow{2}{*}{$\begin{array}{l}1 \text { Kings } \\
21: 10\end{array}$} & בַּרַכְתָת אֶלהִים וְמֶלֶּ & 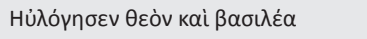 \\
\hline & You blessed God and the king & You blessed God and the king. \\
\hline \multirow{2}{*}{$\begin{array}{l}1 \text { Kings } \\
21: 13\end{array}$} & בַּרַּּ נָבוֹת אֶלהִים וְמֶלֶּ & 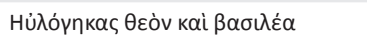 \\
\hline & Naboth blessed God and the king & You have blessed God and the king. \\
\hline \multirow[t]{2}{*}{ Job 1:5 } & 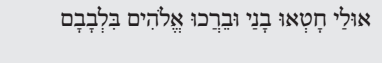 & 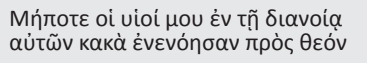 \\
\hline & $\begin{array}{c}\text { Perhaps my sons have sinned and } \\
\text { blessed God in their hearts. }\end{array}$ & $\begin{array}{l}\text { Perhaps my sons have thought bad } \\
\text { things towards God in their mind. }\end{array}$ \\
\hline \multirow[t]{2}{*}{ Job 1:11 } & 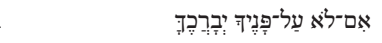 & 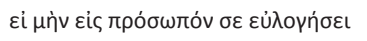 \\
\hline & Surely he will bless you to your face. & Surely he will bless you to your face. \\
\hline \multirow[t]{2}{*}{ Job 2:5 } & 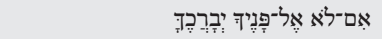 & 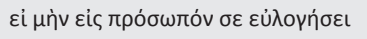 \\
\hline & Surely he will bless you to your face. & Surely he will bless you to your face. \\
\hline \multirow[t]{2}{*}{ Job 2:9 } & בדּרֵּך אֶלהִים וָמְת & 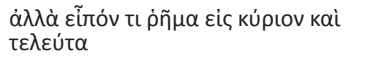 \\
\hline & Bless God and die. & $\begin{array}{l}\text { But say some word to the Lord and } \\
\text { die. }\end{array}$ \\
\hline
\end{tabular}

MT, Masoretic Text; LXX, Septuagint.

For four of the six occurrences of this $\mathrm{BH}$ euphemism, the

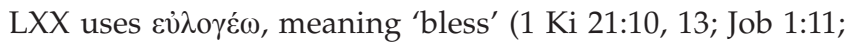
$2: 5)$. This type of lexical correspondence is typical in the Greek renderings of $\mathrm{BH}$ idiomatic expressions (see Mangum

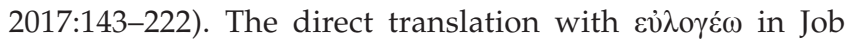
1:11 and 2:5 should probably be considered a Hebraism because the Greek verb does not appear to be used in that sense in other Greek literature (see Liddell, Scott \& Jones

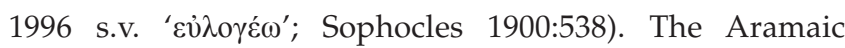
versions (Peshitta and Targum) are surprisingly less euphemistic for these six verses. For these examples, the Aramaic translations generally use verbs that directly convey the negative connotations of these statements. Only the Targum of Job 2:9 appears to follow the pattern of antiphrasis. On these occasions, both the Peshitta and the Targum were apparently unconcerned about using more direct language than the Hebrew, translating the meaning directly (see Mangum 2017:233-235). This likely reflects a weakening of the taboo in the rabbinic period (see Mangum 2017:234-235, 239).

Another tendency in the LXX renderings of $\mathrm{BH}$ figures of speech is that the Greek renderings tend to represent nearly every element of the Hebrew text with a corresponding element in Greek. The LXX rendering of this phrase in Job 1:11 is representative:

\begin{tabular}{|c|c|}
\hline$\varepsilon \hat{\imath}$ & $=$ \\
\hline$\mu \grave{\eta} \nu$ & $=$ \\
\hline cis & $=$ \\
\hline$\pi \rho o ́ \sigma \omega \pi$ ó $\nu \varepsilon \varepsilon$ & $=$ \\
\hline 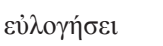 & $=$ \\
\hline
\end{tabular}

The only departures from this type of literal rendering of the $\mathrm{BH}$ phrasing are found in Job 1:5 and 2:9. The speech of Job's wife is greatly expanded in Greek in 2:9, but the expansion provides no obvious motivation for the way the euphemistic expression was translated. 
Similarly, in Job 1:5, there is no immediately apparent reason for the LXX translator to not have translated literally as in Job 1:11 and 2:5. All four uses of the euphemism also appear to have been part of the Old Greek (OG) text, indicating that the different ways of rendering it are not the work of later revisions to the text (see Kutz 1997:11-12). Cook (2010) has demonstrated the strong likelihood that the added material in Job 2:9 is part of the literary work of the original translator.

\section{Job 1:5}

Masoretic Text (MT)

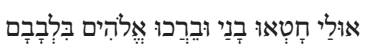

Perhaps my sons have sinned and blessed God in their hearts

LXX

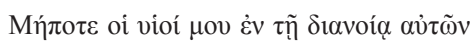

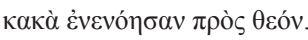

Perhaps my sons have thought bad things towards God in their mind.

In Hebrew, Job's statement includes two verbs: חדטְאו [they sinned] and וּבר [they blessed]. The Greek translator

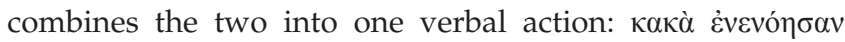
[they thought bad things]. The use of sióvola [mind] as an equivalent for לב [heart] as in Job 1:5 is evident elsewhere in the LXX (e.g. LXX Gen 17:17; 27:41). The Greek translators were often attuned to when לב was used metaphorically for

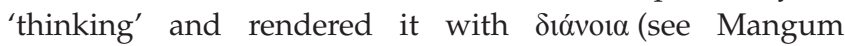
2017:187-188).

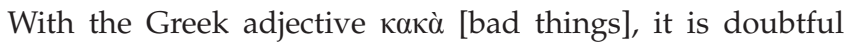

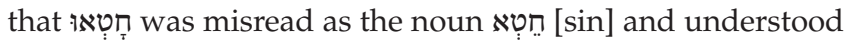
syntactically as an object of ברך. Kutz (1997:12n6) points out that the two occasions where the translator has rendered the euphemism literally with $\varepsilon \dot{\lambda} \lambda \mathrm{o} \gamma \dot{\varepsilon} \omega$ are times 'when it is spoken by the Adversary' and that 'when Job speaks in 1:5 it is paraphrased'. The Greek in Job 1:5 conveys the appropriate meaning whilst avoiding direct reference to sin and blasphemy. However, it is not quite right to call it a paraphrase. The rendering has a literary nuance to it whilst still representing the Hebrew faithfully in a near-literal translation. There is no softening of the scene because кakò can mean 'evil' or 'wicked', and the references in Job 1:5 to sacrifice and purification keep the idea of offense against God near. Rather, the translator has explained what [bless God in their hearts] means - it means thinking bad things about God in mind.

Kutz (1997:222-223) argues that the varying renderings for ברד in Job 1-2 reflect an interpretive stance of the translator that shifts according to whether ברך is used by humans or by 'the Adversary'.

The formal translation equivalent in Job 1:11 and 2:5 could be a reflection of the OG translator's characterisation of the Adversary. If the Adversary was understood to be a demonic figure, then the OG translator may have been unwilling to allow the Adversary to address God in anything but the most respectful manner (Kutz 1997:223).
In other words, the Greek translator retained the use of antiphrasis in Job 1:11 and 2:5 when the Adversary

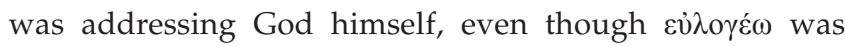
not typically used in that figurative way in ancient Greek. The preservation of the same figure of speech used in $\mathrm{BH}$ prevented the depiction of an enemy standing in God's own throne room announcing, 'you will be cursed', in direct speech. That is, the LXX translator of Job reflects the antiphrasis of the Hebrew text only in the throne room scene and only in direct speech addressed to God.

One characteristic of LXX Job is 'associative translation', where a phrase is inserted that quotes or alludes to another verse in Job or in the LXX corpus (see Cox 2015:387). In one such minor addition in Job 11:2, which draws on phrasing from LXX Job 14:1, the translator uses

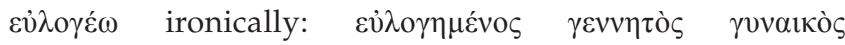
ỏ $\lambda$ ıó́ $\beta 1$ s [blessed is the short-lived offspring of woman]. This could be interpreted as another antiphrastic use

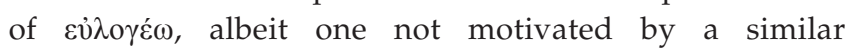
antiphrasis in the source text. The LXX translator of Job does not seem reticent to explicitly have speakers use Greek verbs for cursing, however (see Job 3:2, 6, 8; 24:18), and the mocking context of Job 11 makes it seem likely that the utterance is meant as irony or sarcasm, not as a euphemistic avoidance.

Another explanation must be sought for the use of antiphrasis in the LXX for 1 Kings 21 (3 Kingdoms 20), however. Schorch (2000:251-253) argues for the antiphrastic usage of ברך in 1 Kings and Job arising out of the context of oral language, where speakers avoided openly negative utterances (e.g. the elliptical language of spoken curses). He also rightly notes that the Hebrew scriptures do not universally avoid references to people cursing God (i.e. Is 8:21). Whilst the direct speech argument holds for this use of ברך, the LXX rendering of Job 2:9 also involves direct speech but departs from the pattern of a literal rendering with $\varepsilon \dot{\lambda} \lambda \mathrm{o} \delta \dot{\varepsilon} \omega$. It is likely the LXX renderings of 1 Kings 21:10, 13 and Job 1:11, 2:5 reflect the default, word-for-word literal approach of much of the LXX (Mangum 2017:81n3). Job 2:9 reflects neither antiphrasis nor slavish literalism.

$$
\begin{aligned}
& \text { Job 2:9e }
\end{aligned}
$$

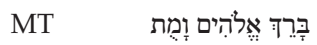

$$
\begin{aligned}
& \text { Bless God and die }
\end{aligned}
$$

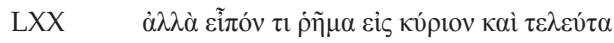

$$
\begin{aligned}
& \text { But say some word to the Lord and die. }
\end{aligned}
$$

In Job 2:9e, instead of commanding Job to 'bless' God and die, Job's wife commands, '[s]ay some word to the Lord and

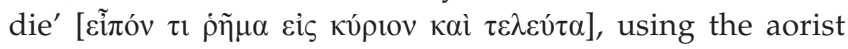
imperative. However, her statement comes as the culmination of a much longer speech in the OG. The bold text in the following quote indicates text that reflects a 
translation of the Hebrew. The rest is material added to Job 2 in Greek (Pietersma \& Wright 1997):

Then after a long time had passed, his wife said to him: How long will you persist and say, 'Look, I will hang on a little longer, while I wait for the hope of my deliverance?' For look, your legacy has vanished from the earth - sons and daughters, my womb's birth pangs and labors, for whom I wearied myself with hardships in vain. And you? You sit in the refuse of worms as you spend the night in the open air. As for me, I am one that wanders about and a hired servant - from place to place and house to house, waiting for when the sun will set, so I can rest from the distresses and griefs that now beset me. Now say some word to the Lord and die! (vv. 9-9e)

This lengthy speech serves to provide a much deeper characterisation of Job's wife (see Kutz 1997:224-227). In the Hebrew text, Job's wife is not a sympathetic figure. She appears without introduction, criticises his insistence on his righteousness and says he may as well 'bless' God directly and end things. Her misunderstanding of the situation and her rush to conclude that Job is in the wrong foreshadow the tone of the speeches to come with Job's friends, and Job dismisses her in the same way he deflects the comments of all his 'miserable comforters' (Job 16:2). His wife's longer address in the Greek, however, draws attention to the reality that Job was not the only one affected by these circumstances (Kutz 1997:226). She, too, lost her children and her livelihood. The statement that she wanders about as a hired servant suggests that she has gone to work to support their basic needs whilst Job just sits around feeling sorry for himself: 'Job's wife has herself undergone considerable suffering and her words reflect the weariness of her own struggle and her sympathy for Job' (Kutz 1997:226). Her final pronouncement that he should 'say some word to the Lord and die' must be understood in the context of this deeper characterisation. Her words are toned down in comparison to the Hebrew text. She does not say Job should say something bad about God or to God. She does not tell him to commit blasphemy. Kutz (1997:226) believes this ambiguity shifts the emphasis 'away from what she urged her husband to say onto the attitude reflected in her words'. The Hebrew emphasises what she wants him to do - 'bless' God. The Greek emphasises her resignation over the situation and her suggestion that it may be time to give up. Her words were meant in the sense of 'make your peace with the Lord and die' (see Kutz 1997:226).

In his study on the additions in LXX Job 2:9, Cook (2010) does not dwell on the meaning of this statement in 2:9e. He understandably reads عĩ̃óv as another euphemism, noting that 'the Greek seemingly avoids referring to "cursing God"' (Cook2010:281). This is a reasonable conclusion (and analysing this phrase was not Cook's purpose), but it is curious that

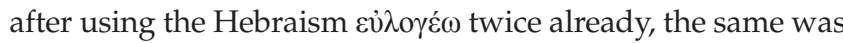
not done here if the point had been to avoid a reference to 'cursing' God. It appears that an explicit choice of a Greek verb meaning 'curse' was out of bounds and would have been considered dysphemistic by the Greek audience.
Both occasions where the translator departed from antiphrasis reflect a more literary, nuanced understanding of the scene. Here the choice of Eĩióv $\tau$ i $\dot{\eta} \tilde{\mu} \alpha$ [say some ברך builds on the added characterisation of Job's wife provided by the additions to Job 2:9.

\section{Conclusion}

In summary, the Septuagint generally approached the euphemistic use of ברך with a literal translation of the euphemistic word. For the Greek audience, the Hebraism was usually employed, but the translators may have expected the audience to track with the figurative usage even though $\varepsilon \dot{\lambda} \lambda \gamma_{\varepsilon} \dot{\varepsilon} \omega$ was not typically used antiphrastically in ancient Greek. For the two cases in LXX Job that do not reflect antiphrasis, the translator has provided stylistic renderings that also reflect an exegesis of the text.

\section{Acknowledgements Competing interests}

The author declares that he has no financial or personal relationships that may have inappropriately influenced him in writing this research article.

\section{Author's contributions}

D.T.M. is the sole author of this research article.

\section{Ethical considerations}

This article followed all ethical standards for research without direct contact with human or animal subjects.

\section{Funding information}

This research received no specific grant from any funding agency in the public, commercial or not-for-profit sectors.

\section{Data availability statement}

Data sharing is not applicable to this article as no new data were created or analysed in this study.

\section{Disclaimer}

The views and opinions expressed in this article are those of the author and do not necessarily reflect the official policy or position of any affiliated agency of the author.

\section{References}

Allan, K. \& Burridge, K., 1991, Euphemism \& dysphemism: Language used as shield and weapon, Oxford University Press, New York, NY.

Allan, K. \& Burridge, K., 2006, Forbidden words: Taboo and the censoring of language, Cambridge University Press, Cambridge.

Baker, M., 2011, In other words: A coursebook on translation, 2nd edn., Routledge, London.

Chau, K., 2014, 'Metaphor's forgotten brother: A survey of metonymy in Biblical Hebrew poetry', Journal for Semitics 23(2), 633-652. https://doi.org/10.25159/ 1013-8471/3510 
Cook, J., 2010, 'Are the additions in LXX Job 2,9a-e to be deemed as the Old Greek text?', Biblica 91(2), 275-284.

Cox, C.E., 1990, 'Vocabulary for wrongdoing and forgiveness in the Greek translation of Job', Textus 15(1), 119-130. https://doi.org/10.1163/2589255X-01501007

Cox, C.E., 2007, 'lob: To the reader', in A. Pietersma \& B.G. Wright (eds.), A new English translation of the Septuagint, pp. 667-670, Oxford University Press, New York, NY

Cox, C.E., 2015, 'Job', in J.A. Aitken (ed.), The T\&T Clark Companion to the Septuagint, pp. 385-400, Bloomsbury T\&T Clark, London.

Ginsburg, C.D, 1897, Introduction to the Massoretico-critical edition of the Hebrew Bible, Trinitarian Bible Society, London.

Habel, N.C., 1985. The Book of Job: A commentary, The Westminster Press, Philadelphia, PA.

Heider, G.C., 1999, 'Molech', in K. Van der Toorn, B. Becking \& P.W. Van der Horst (eds.), Dictionary of deities and demons, pp. 581-585, Brill, Leiden.

Kutz, K.V., 1997, 'The Old Greek of Job: A study in early biblical exegesis', PhD thesis, University of Wisconsin.

Liddell, H.G., Scott, R. \& Jones, H.S., 1996, A Greek-English lexicon, 9th edn., with revised supplement, Clarendon, Oxford.

Mangum, D.T., 2017, 'To conceal or reveal? Self-censorship and explicitation in the ancient Bible versions', PhD thesis, University of the Free State.

Noegel, S.B., 2013, 'Euphemism in the Hebrew Bible', in G. Khan (ed.), Encyclopedia of Hebrew language and linguistics, vol. 1, pp. 869-871, Brill, Leiden.

Opelt, I., 1966, 'Euphemismus', in T. Klauser (ed.), Reallexikon für Antike und Christentum, vol. 6, pp 947-964, Hiersemann, Stuttgart.
Paul, S.M., 2005, Divrei Shalom: Collected studies of Shalom M. Paul on the Bible and the ancient Near East, 1967-2005, Brill, Leiden.

Paul, S.M., 2007, 'Euphemism and dysphemism', in F. Skolnik \& M. Berenbaum (eds.), Encyclopaedia Judaica, 2nd edn., vol. 6, pp. 549-550, Macmillan, Detroit.

Pietersma, A., \& Wright, B.G. (eds.), 2007, A new English translation of the Septuagint, Oxford University Press, New York, NY.

Pope, M.H., 1973, Job: Introduction, translation, and notes, Doubleday, New York, NY. Pope M.H, 1992, 'Bible, euphemism and dysphemism in the', in D.N. Freedman (ed.), The Anchor Bible dictionary, vol. 1, pp. 720-725, Doubleday, New York, NY.

Puech, E., 1999, 'Milcom', in K. Van der Toorn, B. Becking \& P.W. Van der Horst (eds.), Dictionary of deities and demons, pp. 576-576, Brill, Leiden.

Schorch, S., 2000, Euphemismen in der Hebräischen Bibel, Harrassowitz, Wiesbaden.

Sophocles, E.A., 1900, Greek Lexicon of the Roman and Byzantine Periods (From B. C. 146 to A. D. 1100), Scribner's, New York, NY.

Toury, G., 2012, Descriptive translation studies and beyond, rev. edn., John Benjamins, Amsterdam.

Tov, E., 2012, Textual criticism of the Hebrew Bible, 3rd edn., Fortress, Minneapolis, MN.

Warren-Rothlin, A., 2013, 'Euphemisms and Bible translations', in G. Khan (ed.), Encyclopedia of Hebrew language and linguistics, vol. 1, pp. 865-869, Brill, Leiden.

Zevit, Z., 2011, 'Syntagms in Biblical Hebrew: Four short studies', in G. Geiger (ed.), En pase grammatike kai sophia: Saggi di linguistica ebraica in onore di Alviero Niccacci, Ofm, pp. 393-403, Franciscan Printing Press, Jerusalem. 